\title{
MALAM MINGGU BERSAMA BUKU (M2B2) SEBAGAI INKUBASI LITERASI BAGI KAUM MILENIAL DI KECAMATAN GREGED KABUPATEN CIREBON
}

\author{
Aip Syarifudin', Abdul Muaz ${ }^{2}$, Whisnu Sentosa ${ }^{3}$ \\ 1,2Universitas Muhammadiyah Cirebon, Cirebon 45153, Indonesia \\ 3Peneliti Indo Consulting Network, Jakarta Selatan 12120, Indonesia \\ aip.syarifudin@umc.ac.id
}

\begin{abstract}
The development of the digital era not only has a positive impact but has a negative effect. Like metal coins with two sides, one side of the presence of the digital era is very helpful for knowledge and insight because of the rapid flow of information and technological advances. On the other hand, the digital era is a scourge, especially for millennials and school-age children. Many facts show the dependence of youth and school-age children on devices. Even the loss of family interaction and social interaction. In terms of education, the main source of reference has shifted from shifting books to gadgets as a reference for searching when doing school work and enriching insights. Referring to the global development system, national development cannot only rely on the responsibility of the government (state) as a policy maker. It needs community involvement (Civil Society) so that there is a complete synergy. From the community side, there are several groups that make this issue a realm of service to improve aspects of the quality of human resources in the future. One of them is Malam Minggu Bersama Buku (M2B2). A forum for youth and school-age children who bave the goal of becoming an incubation of literacy culture in their hometown. This study aims to determine the role of M2B2 in an effort to increase reading interest for youth and school-age children in Greged District, Cirebon. This research uses descriptive qualitative research methods with purposive sampling technique with direct interviews (in-dept Interview) and confirms the data with Participatory Action Research (PAR) techniques to accurately dig deeper into the data in the field.

Keywords: Digital Era, Incubation, Literacy, Millennial.
\end{abstract}

\begin{abstract}
ABSTRAK
Berkembangnya era digital bukan hanya berdampak positif namun memiliki efek negatif. Seperti koin logam dengan dua sisi, satu sisi kehadiran era digital sangat membantu pengetahuan dan wawasan lantaran begitu cepatnya arus informasi dan kemajuan teknologi. Sisi lain justru era digital menjadi momok khususnya bagi kaum milenial dan anak usia sekolah. Banyak fakta memperlihatkan tergantungannya kaum muda dan anak usia sekolah pada gawai. Bahkan hilangnya interaksi keluarga dan interaksi sosial. Dalam hal pendidikan, sumber utama referensi sudah beralih dari buku bergeser menjadi gawai sebagai rujukan pencarian saat pengerjaan tugas sekolah maupun pengayaan wawasan. Merujuk pada sistem pembangunan global, pembangunan bangsa tidak bisa hanya disandarkan pada tanggung jawab pemerintah (state) sebagai pemangku kebijakan. Perlu keterlibatan masyarakat (Civil Society) sehingga terjalin sinergitas yang utuh. Dari sisi masyarakat terdapat beberapa kelompok yang menjadikan issues ini sebagai ranah pengabdian untuk meningkatkan aspek kualitas sumber daya manusia di masa depan. Salah satu diantaranya adalah Malam Minggu Bersama Buku (M2B2). Suatu forum kaum muda dan anak usia sekolah yang memiliki cita menjadi inkubasi budaya literasi di kampung halamannya.Penelitian ini bertujuan untuk mengetahui peran dari M2B2 dalam upaya meningkatkan minat baca untuk pemuda dan anak usia sekolah di Kecamatan Greged, Cirebon. Penelitian ini menggunakan metode penelitian deskriptifkualitatif dengan Teknik Purposive Sampling dengan wawancara langsung (in-dept Interview) dan mengkonfirmasikan data dengan teknik Participatory Action Research untuk menggali secara akurat data di lapangan lebih mendalam.
\end{abstract}

Kata Kunci: Era Digital, Inkubasi, Literasi, Milenial.

Submitted Oct 28, 2020 | Revised Nov 07, 2020 | Accepted Nov 11, 2020

\section{Pendahuluan}

Menurunnya budaya literasi terjadi di pelbagai wilayah karena era digital. Fakta empiris begitu terasa saat anak-anak usia sekolah hendak mengerjakan PR (Pekerjaan Rumah). Saat ini gawai sebagai sumber referensi dari setiap persoalan, anak-anak didik dipermudah mencari informasi yang belum difahami melalui browsing ataupun yang lainnya. Sangat sedikit anak-anak sekolah saat ini menjadikan 
buku sebagai sumber referensi utama dalam setiap pekerjaan rumah maupun dalam pengayaan pengetahuannya. Begitupun dampak negatif era digital dewasa ini adalah menurunnya interaksi sosial. Terdapat banyak fakta memperlihatkan anak-anak sekolah lebih asyik memainkan gawai sebagai saluran hiburan dengan games atupun memainkan social media.

Fenomena menurunnya budaya literasi adalah hal yang serius sehingga menjadi bahan analisa dengan problem solving yang tepat. Hal ini dikarenakan menyangkut kemampuan sumber daya manusia di masa mendatang.Melalui Kementerian Pendidikan dan Kebudayaan RI mencanangkan program Gerakan Literasi Nasional (GLN). Program ini diantaranya; Gerakan Literasi Sekolah, Gerakan Indonesia Masyarakat, dan Gerakan Literasi Keluarga didalam buku panduan yang disusun oleh pemerintah (Kemendikbud, 2017).

Perhatian terhadap menurunnya budaya literasi tidak hanya dilakukan oleh pemerintah. Masyarakat sebagai Civil Society turut berkontribusi menggalakan program agar meningkatnya budaya literasi. Seperti riset Yanto (2016) yang mendeskripsikan model aktivitas gerakan literasi berbasiskan komunitas di Sudut Baca Soreang. Dikawasan priangan timur misalnya, gerakan Rumah Imperium di Kabupaten Sumedang juga melakukan upaya peningkatan literasi dengan program gerobak baca keliling. Selain Yanto, meningkatkan budaya literasipun diteliti oleh Yulisa(2017) menyebutkan bahwa gerakan literasi mampu menjadi pembentuk pendidikan berkarakter di sekolah. Seperti membiasakan membaca buku 15 menit di awal pelajaran dalam suasana yang menyenangkan dan nyaman. Dari pembiasaan yang dilakukan ini menjadikan siswa-siswa bisa meningkatkan minat baca dan meningkatkan prestasi akademik di sekolah.

Selama ini penguatan untuk meningkatkan minat baca dan budaya literasi tersebut masih dilakukan secara parsial. Tantangan tersebut berlanjut pada golongan milenial yang menjadi figur bermasyarakat. Usia muda di Indonesia khususnya sedang dalam kondisi puncak emasnya yaitu mencapai 66.3 Juta Jiwa. Kondisi ini mengharuskan milenial untuk terus bergerak dan berkarya bagi masyarakat, seperti adagium kemajuan suatu bangsa ditentukan oleh generasi muda. Generasi muda adalah bagian dari masyarakat yang kelak akan melanjutkan estafeta kepemimpinan di masa yang akan datang.

Negara ini membutuhkan generasi yang berkarakter dan berpengetahuan luas karena generasi mudalah yang mampu bersaing dalam kompetisi global. Peningkatan kualitas sumber daya manusia dimulai dari kemauan membaca sebagai jendela dunia. Terbukanya jendela dunia tersebut bisa diawali dari dimulainya keinginan masyarakat secara sadar dan bersama-sama untuk melakukan kegiatan positif yaitu membaca. Seperti yang di rilis oleh Central Connecticut State University (CCSU)pada tahun 2016 Indonesia menempati peringkat ke 60 dari 61 negara yang di survey dalam hal kemampuan literasi. Hasil survei tersebut mengisyaratkan bahwa minat baca dan literasi bangsa Indonesia dalam kondisi yang memprihatinkan (Jakarta Post, 2016).

Sudah menjadi suatu keharusan bahwa peningkatan minat baca perlu ditingkatkan. Selama tiga dekade terakhir, lembaga pemerintah secara aktif menggalakkan program-program untuk meningkatkan kualitas minat baca. Meskipun demikian, kesadaran pentingnya budaya literasi masih sangat kurang, padahal kualitas budaya literasi berbanding lurus dengan kualitas sumber daya manusia.

Bertemali dengan hal itu, gerak milenial yang tidak terbatas sebagai agen perubahan ini tentu menjadi pijakan baru bagi masyarakat untuk berkembang. Seperti kata pepatah "Membaca dapat membuka jendela dunia" yang berarti bahwa kita dapat memperoleh cakrawala dan wawasan lebih luas lagi dengan cara membaca. Salah satunya di wilayah Kabupaten Cirebon, Kecamatan Greged. Milenial Greged ini menawarkan konsep baru sebagai upaya percepatan peningkatan literasi melalui program Malam Minggu Bersama Buku (M2B2).

Berangkat dari fakta empiris tersebut penulis ingin mengangkat aktivitas M2B2 sebagai partisipasi aktif dari masyarakat (Civil Society) di wilayah Cirebon Timur, Kecamatan Greged. Suatu kawasan 
pedesaan yang cukup menjadi perhatian karena kesadaran pendidikan masih rendah terlebih dihadapkan pada era digital saat ini.

Pertanyaan kritisnya adalah bagaimana peran M2B2 sebagai komunitas yang melakukan kegiatan literasi edukasi pada kaum muda dan usia anak sekolah di Kecamatan Greged. Kemudian bagaimana M2B2 menyikapi era digital yang notabene menjadikan kaum muda dan anak usia sekolah bergantung pada penggunaan gawai. Dua hal inilah menjadi rumusan masalah yang akan ditelusuri dalam kesempatan penelitian ini.

Tujuan dari penelitian ini adalah mendeskripsikan peran dari M2B2 pada kaum muda Greged dalam pembangunan budaya literasi, selain itu mendeskripsikan peran M2B2 dalam mensosialisasikan pentingnya tidak bergantung pada gawai. Secara mendalam penulis ingin menjadikan riset ini sebagai sumbangsih akademik sehingga menejadi rujukan dalam bidang pendidikan mengenai rendahnya budaya literasi di Indonesia. Penulis berharap hasil penelitian ini dapat menjadi perhatian para pegiat literasi. Secara umum agar memudahkan dalam membaca skema penelitian ini penulis gambarkan dalam kerangka berfikir sebagai berikut.

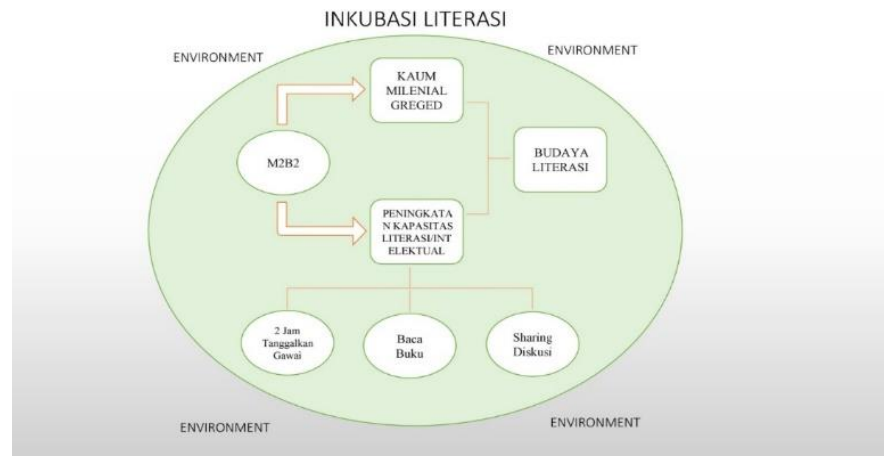

Gambar 1. Kerangka Berfikir

\section{MetodePenelitian}

Penelitian ini dilakukan dengan menggunakan desain penelitian deskriptif kualitatif. Bungin(2007) dalam Data kualitatif diungkapkan dalam bentuk kalimat serta uraian-uraian bahkan berupa cerita pendek. Berkaitan dengan hal itu, data kualitatif dalam penelitian ini yaitu berupa obrolan, tindakan, sumber data tertulis, foto serta diagram statistik yang relevan dengan penelitian. Peneliti melakukan analisa data kualitatif sebagai upaya dari eksplorasi data, mengorganisasikan data, mengklasifikasikannya menjadi satuan yang dapat dikelola, mensintesiskannya, mencari dan menemukan pola, menemukan hal yang utama serta hal yang dipelajari, dan memutuskan apa yang dapat diceritakan kepada orang lain. Pada tahap tersebut data diperoleh dari menelaah seluruh data dari berbagai sumber yaitu wawancara, pengamatan, yang sudah dituliskan dalam catatan lapangan, telaah dokumen, foto, dan sebagainya.

Teknik dalam penelitian ini menggunakanpurposive sampling. Teknik purposive samplingdilakukan dengan cara mengambil subyek penelitian dan bukan didasarkan pada strata, random, atau daerah, tapi didasarkan atas tujuan tertentu. Beberapa alasan menggunakan teknik purposive dalam penelitian ini sebagai berikut; Pertama, karena peneliti ingin mengambil informan hanya dari sumber yang berkaitan dengan masalah penelitian. Hal ini seperti dikatakan Moleong (2012) bahwa yang menjadi informan dalam teknik purposive hanyalah sumber yang bisa memberi informasi tentang situasi dan kondisi latar penelitian. Kedua, peneliti memetakan sumber informasi dalam masalah penelitian. Pada penelitian ini informan diklasifikasikan kedalam empatcluster yakni informan dari pengurus komunitas M2B2, informan dari pemerintahan desa, informan dari anggota M2B2, serta informan dari masyarakat. Pengklasifikasian tersebut dapat terlihat dari tabel informan sebagai berikut: 
Tabel 1. Tabel Informan

\begin{tabular}{|c|c|c|c|}
\hline No & Klasifikasi Informan & Nama/Jabatan & Informasi yang diperoleh \\
\hline 1 & Pengurus komunitas M2B2 & $\begin{array}{ll}\text { 1. } & \begin{array}{l}\text { Ketua/Founder } \\
\text { komunitas M2B2 }\end{array} \\
\text { 2. } & \begin{array}{l}\text { Sekretaris } \\
\text { komunitas M2B2 }\end{array}\end{array}$ & $\begin{array}{l}\text { Untuk mendapatkan informasi } \\
\text { peran M2B2 pada kaum muda } \\
\text { di Kecamatan Greged termasuk } \\
\text { program komunitas dan data } \\
\text { lainnya }\end{array}$ \\
\hline 2 & Pemerintahan Desa & 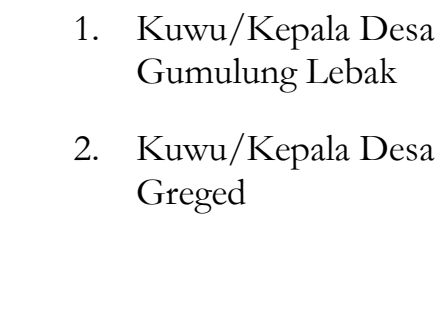 & $\begin{array}{l}\text { Untuk mendapatkan informasi } \\
\text { mengenai kegiatan M2M2 } \\
\text { dilingkungan desa tersebut. } \\
\text { Menggali informasi hasil dari } \\
\text { kegiatan M2B2 pada kaum } \\
\text { muda di desa wilayah } \\
\text { Kecamatan Greged }\end{array}$ \\
\hline 3 & $\begin{array}{l}\text { Anggota M2B2/peserta } \\
\text { forum }\end{array}$ & $\begin{array}{l}\text { Diambil sampel } 6 \text { orang } \\
\text { sebagai informan yang } \\
\text { mewakili jenjang usia; usia } \\
\text { anak sekolah dasar sejumlah } \\
2 \text { orang, usia sekolah } \\
\text { menengah pertama dan } \\
\text { menengah atas sejumlah } 2 \\
\text { orang dan usia dewasa } \\
\text { sejumlah } 2 \text { orang }\end{array}$ & $\begin{array}{l}\text { Untuk menggali informasi efek } \\
\text { dari M2B2 pada para peserta. } \\
\text { Pada penggalian data ini } \\
\text { termasuk menelusuri informasi } \\
\text { sebelum dan sesudah adanya } \\
\text { forum M2B2 }\end{array}$ \\
\hline 4 & Masyarakat & $\begin{array}{l}\text { Diambil } 2 \text { tokoh masyarakat } \\
\text { berpengaruh di locus } \\
\text { penelitian }\end{array}$ & $\begin{array}{l}\text { Pada informan ini peneliti ingin } \\
\text { mendapatkan analisa dan } \\
\text { asumsi warga terhadap } \\
\text { berjalannya program M2B2 } \\
\text { dilingkungannya. Sehingga } \\
\text { peneliti mendapatkan } \\
\text { konfirmasi dari data } \\
\text { sebelumnya yang didapatkan }\end{array}$ \\
\hline
\end{tabular}

Peneliti menggunakan jenis wawancara mendalam (in depth interview). Wawancara mendalam adalah proses mendapatkaninformasidalam menelitimelaluitanya jawab sambil bertemu langsung antara peneliti dan informan (Bungin, 2007). Peneliti melakukan wawancara secara mendalam (in-dept Interview) dengan metode wawancara tertutup pada sejumlah informan kunci, kemudian peneliti juga melakukan wawancara terbuka terhadap masyarakat Greged untuk mengkonfirmasi hasil dari wawancara tertutup tersebut dengan menggunakan tekhnik Participatory Action Research (PAR). Melalui teknik ini peneliti terjun langsung dilapangan sehingga mendapatkan informasi yang mendalam.

\section{Hasil dan Pembahasan}

Literasi memiliki dua makna; pertama, kemampuan dalam hal menulis dan membaca. Kedua, pengetahuan atau keterampilan dalam bidang atau aktivitas tertentu. Dalam buku Literacy: Profile of America's Young Adult memberikan definisi literasi sebagai kemampuan seseorang dalam menggunakan informasi untuk mengembangkan pengetahuan sehingga dapat mendatangkan manfaat bagi masyarakat (Kirsch dan Jungeblut, 2002). Sedangkan American Library Association (1998) dalam Information Literacy Standart menyebutkan bahwa literasi adalah komponen penting yang harus dimiliki oleh setiap warga dan berkontribusi dalam mencapai pembelajaran sepanjang hayat (Long Live Learning). Berkaca pada definisi tersebut, peneliti menyimpulkan literasi bukan hanya kemampuan membaca dan menulis, tetapi 
literasi bisa diartikan melek teknologi, politik, berpikir kritis, dan peka terhadap lingkungan sekitar, karena menyangkut kemampuan menggunakan informasi dalam pengembangan pengetahuan sehingga berdampak kemaslahatan pada sekitar.

Penelitian ini akan mendeskripsikan peran M2B2 dalam pembangunan budaya literasi di Kecamatan Greged Cirebon khususnya pada kaum muda dan anak usia sekolah. Menjadi unik penelitian ini karena unit analisis adalah kaum muda dan anak usia sekolah. Menurut Bramley (1991) setiap individu harus memiliki keterampilan sosial serta pengetahuan yang memadai untuk dapat hidup di era informasi. Selain itu, Komisi Perencanaan Pendidikan pada National Association American (dalam Mappiare, 1982) menjabarkan gerenasi muda dan remaja memiliki kebutuhan yang bersifat khas sebagai berikut:

1. Remaja merasa butuh untuk mengembangkan keterampilan yang dapat digunakan sebagai bekal untuk bekerja.

2. Remaja sangat memerlukan informasi untuk memelihara kesehatan dan kesegaran fisiknya.

3. Remaja membutuhkan suatu informasi atau pengetahuan tentang hak dan kewajiban sebagai warga negara yang baik.

4. Memerlukan pengetahuan tentang masalah keluarga dan maknanya bagi individu maupun masyarakat.

5. Memerlukan informasi dan pengetahuan mengenai bagaimana memperoleh dan memanfaaatkan fasilitas yang ada dan bagaimana cara pemeliharaannya.

6. Butuh informasi tentang peranan ilmu pengetahuan (science) bagi kehidupan manusia.

7. Membutuhkan peresapan makna dan penghargaan terhadap seni, musik, dan keindahan alam.

8. Memerlukan informasi bagaimana cara memanfaatkan waktu luangnya dengan baik.

9. Membutuhkan pengetahuan tentang cara mengembangkan rasa hormat (respect) pada orang lain.

10. Membutuhkan wawasan dan pengetahuan untuk mampu berfikir secara rasional.

Bisa disimpulkan budaya literasi sangat dibutuhkan bagi kaum muda dan anak usia sekolah. Karena budaya literasi menyangkut bagaimana kaum muda dan anak usia sekolah mendapatkan informasi dan mengelola informasi dalam menyikapi fenomena sosial. Perlu menjadi benang merah adalah apakah selama ini metode membaca sebagai pendekatan meningkatkan budaya literasi dianggap kurang disukai kaum muda dan anak usia sekolah. Bisa dibayangkan dengan fakta begitu rendahnya budaya literasi di Indonesia. Artinya perlu metode kekinian agar gemar membaca dan berdiskusi dimintai oleh kaum muda dan anak usia sekolah sehingga tidak berkesan membosankan.

Malam Minggu Bersama Buku (M2B2) menggunakan model pendekatan yang dibangun dengan saling berinteraksinya pemuda setempat. Interaksi tersebut dimulai dari membaca dan berdiskusi dengan waktu kurang lebih 2 jam serta menjauhkan gawai saat melakukan kegiatan tersebut. M2B2 ini menjadi langkah tindakan dari mulai menurunnya minat baca dan literasi dikalangan pemuda di desa. Langkah yang efisien bisa diawali dari munculnya peraturan dan dukungan dari masyarakat sebagai unsur terkecil penggerak perubahan.

Momentum penelitian ini bukan hanya peneliti terjun dilapangan, melainkan berada ditengah masyarakat Greged sendiri. Participatory Action Research yang dilakukan oleh peneliti memungkinkan peneliti untuk benar-benar mendapatkan data yang sedalam mungkin sesuai dengan kaidah kualitatif. Dalam hal ini, peneliti merasakan langsung kondisi sebelum adanya program M2B2 dan pasca terselenggaranya forum ini.

Pada kondisi masyarakat Greged, kesadaran akan pentingnya pendidikan sedikit terabaikan. Kondisi ekonomi dan sosiologis sangat menentukan pola pikir para orang tua di kawasan ini. Kebanyakan para orang tua di wilayah ini mendidik anak dengan membangun kesadaran untuk membantu ekonomi rumah tangga orang tua dikemudian hari. Fakta ini sangat terasa begitu banyaknya anak usia sekolah yang memutuskan tidak melanjutkan kuliah dan memilih kerja, atau tidak 
melanjutkan pada jenjang SMP atau sederajat, lebih parah dari itu terdapat beberapa anak usia sekolah yang putus Sekolah Dasar atau dianggap cukup hanya mengenyam pendidikan dasar.

Fakta lain, beberapa warga di kawasan ini berhasil menyekolahkan atau memberikan support pada anaknya untuk mengenyam pendidikan tinggi. Terdapat dua fenomena pada kondisi ini; pertama, mereka yang berhasil mengenyam pendidikan tinggi akhirnya berkarir di luar kota (hijrah). Kedua, fenomenanya beberapa diantara mereka yang mendapatkan kesempatan pendidikan tinggi tetap dikampung halamannya dengan kreasi organisasi guna terjadinya transfer knowledge pada kaum muda dan usia anak sekolah lainnya.

M2B2 adalah forum yang menjadi program rutinitas dengan rancangan para kaum cendikia milenial di kampung Greged. Pendiri forum ini adalah alumnus salah satu perguruan tinggi di Cirebon yang berhasil mengumpulkan kaum muda pendidikan lainnya untuk membangun kesadaran membaca. Pengurus dari forum M2B2 diantaranya lulusan perguruan tinggi, lulusan Sekolah Menengah Atas (SMA) atau sederajat sedangkan anggotanya kebanyakan adalah kaum muda dan anak usia sekolah baik yang mengantongi izajah SMA, ataupun SMP bahkan SD, termasuk yang putus sekolah.

Saat penelitian ini dilakukan, terdapat beberapa kemudahan dalam mencari data dan mengolahnya, salah satunya karena keterbukaan dan keramahan warga maupun unit analisis serta dukungan dari para Kuwu sekitar, tokoh masyarakat dan kerjasama dengan pengurus M2B2 yang baik. Para anggota M2B2 pun sangat terbuka, hal unik dirasakan efek dari forum ini adalah rasa penyesalan mendalam dari para anggota M2B2 karena tidak melanjutkan jenjang sekolah. Keadaan ini adalah efek positif dari stimulus yang terus di lakukan oleh forum ini mengenai pentingnya pendidikan. Dua hal bukti adanya rasa sesal tersebut; pertama, beberapa diantaranya menganggap cukup hanya dirinya yang tidak atau belum tuntas menuntut ilmu di lembaga formal. Sebagai bentuk nyata dari hal itu pada akhirnya mereka mendukung bagian dari keluarganya untuk berpendidikan hingga tuntas. Kedua, sebagian dari mereka memilih melanjutkan dengan mengejar paket sebagai upaya meningkatkan jenjang pendidikan formal.

Forum M2B2 bak oase di tanah tandus. Kehadiran forum ini mendapat perhatian positif dimata kaum muda Greged. Keberhasilan menjadikan buku sebagai sahabat, mensajikan kajian secara santai dan riang membuat kaum muda dan anak usia sekolah tidak terbebani dengan rutinitas tersebut. Hasil penelitian memperlihatkan grafik yang unik dilihat dari antusiasme para anggotanya. Data pengunjung setiap minggu menunjukan kehadiran yang meningkat. Kaum muda dan anak usia sekolah di wilayah ini menjadikan M2B2 sebagai sarana berkumpul. Kehadiran kaum muda dan anak usia sekolah yang menjadi anggota M2B2 dapat terlihat pada gambar 2 dibawah ini

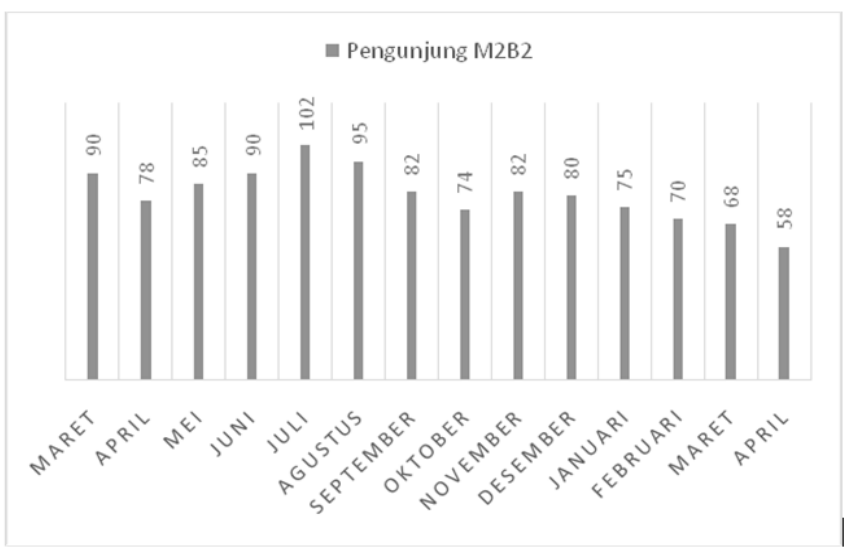

Gambar 2. Data Kehadiran di M2B2

Dalam Gambar 2. Di atas sejak Maret 2019, menunjukan jumlah kehadiran pemuda di desa, setiap bulannya rata-rata sebanyak 80 orang untuk mengikuti kegiatan atau member M2B2. Juli 2019 menjadi puncak tertinggi yaitu sebanyak 102 orang yang mengikuti M2B2. Diantara data di atas tersebut 
terdapat beberapa murid dari siswa SD dari sekolah dasar setempat bahkan terdapat pula siswa yang putus sekolah. Para siswa SD tersebut tidak canggung untuk membaca, dan berdiskusi bersama seniorseniornya. Hal ini membuktikan bahwa M2B2 menjadi katalisator dan stimulus dalam meningkatkan wawasan pengetahuan serta literasi minat baca. Selanjutnya terdapat data yang menunjukan kesukaan topik bacaan yang diminati oleh pemuda saat hadir di M2B2 seperti pada Gambar 3 dibawah ini

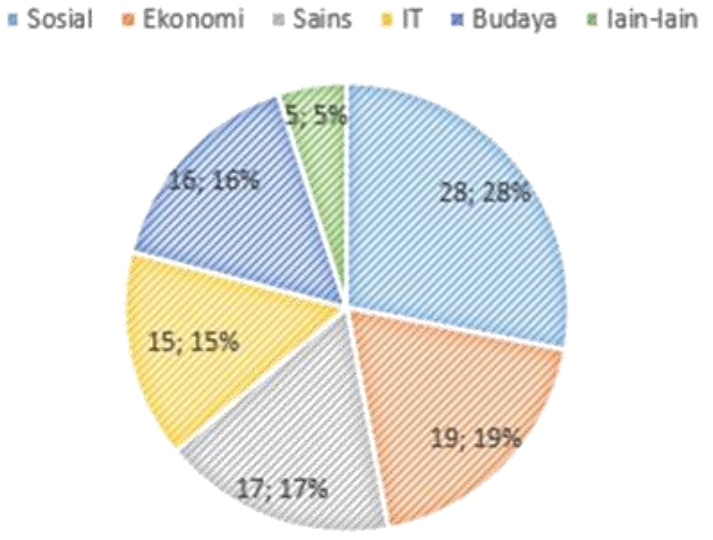

Gambar 3. Data Tema Yang diminati

Pada Gambar 3. Data menunjukan sosial dan ekonomi menjadi tema yang paling diminati untuk dibaca saat berkumpul di M2B2. Kesukaan tema sosial mendapatkan 28 persen dan Ekonomi sebesar 19 persen. Data ini menunjukan bahwa pemuda-pemudi di Greged menyukai bacaan yang bertema sosial dan ekonomi. Selain dari bertema sosial dan ekonomi, pemuda pun masih memiliki preferensi bacaan yang lain diantaranyabudaya, IT, sains, dan lain-lain.

Secara praktis dalam program forum ini, akan dilakukan skema pengelompokan bakat minat dari para anggota forum. Pengelompokan tersebut dilihat dari hasil bacaan dan kecenderungan interaksi sosial saat kajian dan sharing. Kedepan upaya ini akan disinergiskan dengan adanya mentor-mentor dengan klasifikasi yang beragam. Seperti mentor yang dikhususkan untuk mentoring membuka mindset wirausaha, pendidikan, keagamaan dan sosial.

Selain itu, kaum muda dan anak usia sekolah yang telah bergabung di M2B2 ini sudah mengetahui baik dan buruknya era digital. Buku yang tersedia di M2B2 menjadi pemandu member M2B2 dalam kehidupan bermasyarakat. Member di forum ini sudah memahami kecanggihan teknologi yang saat ini telah berkembang di masyarakat. Adanya teknologi saat ini bermanfaat bagi masyarakat luas seperti saling terhubung satu sama lain dan mengakses informasi digital.

Terdapat dua hal penyikapan M2B2 terhadap era digital saat ini. Pertama, dengan aktivitas rutin mingguan membaca dan mengkaji buku selama kurang lebih 2 jam maka menjauhkan sejenak ketergantungan anggota M2B2 pada gawai masing-masing. Kedua, pada setiap kesempatannya kajian ini selalu mensosialisasikan tentang bagaimana menyikapi secara positif era digital tanpa harus bergantungan, sehingga diharapkan buku tetap menjadi sumber referensi utama anggota M2B2 dalam pengembangan wawasannya. Salah satu output yang diharapkan adalah tetap terjalinnya komunikasi interaktif sosial baik di keluarga masing-masing maupun secara pertemanan.

Adanya M2B2 menjadikan kaum muda dan anak-anak usia sekolah Greged melek literasi dan terjadi peningkatan dalam berinteraksi sosial dan budaya. Hal itu didukung dari adanya pemahaman tekstual hingga kontekstual, di adopsi dari Indeks Alibaca (Aktifitas Literasi Membaca) menyatakan ada empat faktor yang memiliki peran penting dalam mendukung aktivitas literasi yaitu dimensi kecakapan, dimensi akses, dimensi alternatif, dan dimensi budaya (Miller dan Mc Kenna, 2016).

Dimensi kecakapan merupakan gambaran mengenai tingkat kecakapan masyarakat dalam mengakses bahan bacaan. Dimensi Akses merupakan gambaran mengenai ketersediaan sumber daya 
literasi baik di sekolah maupun di masyarakat. Dimensi Budaya merupakan dimensi yang menggambarkan sejauh mana kebiasaan atau perilaku masyarakat dalam mengakses bahan-bahan literasi. Sedangkan dimensi Alternatif merupakan Gambaran mengenai opsi atau kemungkinan yang disediakan oleh perangkat elektronik dan digital dalam mengakses informasi baik di sekolah maupun masyarakat.

Jika dikorelasikan dengan pendapat Miller dan Mc Kenna mengenai dimensi yang mendukung budaya literasi. Peneliti memberikan indikator sebagai turunan dari dimensi tersebut dengan mengkontekstualisasikan di lapangan. Tiga indikator sebagai acuan peneliti antara lain; pertama, adanya interaksi literasi. Kedua, tersedianya buku penunjang. Ketiga, keberanian dalam berargumentasi dan menyampaikan ide maupun pendapat.

Fenomena kurangnya budaya literasi seperti ini secara pelan berubah dengan diawali kesadaran membeli buku dan menjadikan sebagai sumbangan untuk kepentingan masyarakat umum. Kemudian secara perlahan dari satu minggu ke minggu yang lain mulai ramai saling berargumentasi menyampaikan gagasan dan ide masing-masing anggota M2B2. Hal empiris terlihat dari kegiatankegiatan yang dilakukan oleh pemuda desa karang taruna maupun acara yang diselenggrakan oleh desa. Berbekal pengayaan dari kajian rutin, anggota M2B2 berperan aktif pada setiap aktivitas diluar M2B2. Hal ini tergambar melalui tiga indikator budaya literasi yang peneliti analisa sebelum dan sesudah berjalannya program M2B2 yaitu:

Tabel 2. Sebelum dan Sesudah ada M2B2

\begin{tabular}{ll}
\hline \multicolumn{1}{c}{ Sebelum M2B2 } & \multicolumn{1}{c}{ Setelah M2B2 } \\
\hline Tidak ada Interaksi Literasi & Ada Interaksi Literasi \\
Tidak Tersedia Buku Penunjang & Ada Buku Penunjang Literasi \\
Malu Beragumentasi & Berani Beragumentasi \\
\hline
\end{tabular}

Dari Tabel 2. Di atas menunjukan bahwa terjadinya pola perubahan dari anggota forum M2B2.Kondisi sebelumnya secara umum malu untuk berargumentasi dalam berinteraksi menjadi berani berargumentasi dan berekspersi, dilihat dari keaktifan anggota saat rutinitas forum maupun diluar forum. Pada kondisi diluar forum misalnya anggota M2B2 terlibat aktif di masyarakat dengan mengikuti kegiatan karang taruna di desa atau kegiatan sosial yang diselenggrakan oleh desa. Anggota M2B2 sering terlibat aktif didalam komunitas masyarakat untuk memberikan ide, gagasan, dan masukan serta turut berkontribusi dalam pembangunan di desanya. Dari adanya perubahan yang terjadi di Greged tersebut dapat disimpulkan bahwa peningkatan budaya literasi meningkat.

\section{Kesimpulan}

Komunitas M2B2 sangat berperan dalam mengembangkan minat baca dan literasi bagi kaum muda dan usia anak-anak sekolah di Kecamatan Greged. Tujuan dari gerakan yang dilakukan para pemuda ini untuk menghidupkan kembali budaya membaca buku dan mendorong warganya untuk terus belajar. M2B2 menjadi wadah inkubasi literasi melalui kajian dan buku-buku yang disediakan.

Anggota M2B2 telah mengetahui dampak buruk dan baiknya era digital. Melalui membiasakan 2 jam bersama buku menjadikan rutinitas para anggota M2B2 tidak bergantung pada penggunaan gawai, menjadikan buku sebagai sumber referensi utama. Secara perlahan sosialisasi mengenai dampak kebergantungan terhadap gawai terus di lakukan M2B2 sehingga meningkatkan budaya literasi dan interaksi sosial.

Budaya Literasi di wilayah Cirebon Timur, Kecamatan Greged khususnya pada kaum muda dan anak-anak usia sekolah yang menjadi angota M2B2 semakin meningkat. Hal ini ditandai tiga indikator; 1) adanya interaksi literasi, 2) tersedianya buku penunjang literasi, 3) kepercayaan diri untuk berargumentasi dan berpendapat menyampaikan gagasan dan ide di kalangaan anggota M2B2. Gambaran sejalan dengan ini terlihat dari partisipasi aktif para anggota M2B2 diluar aktivitas M2B2 
seperti pada acara peringatan hari kemerdekaan RI yang diselenggarakan oleh aparat desa, acara pengajian keagamaan, maupun acara sosial lainnya.

\section{Daftar Pustakan}

A.L.A.(1989). Glossary of Library Terms. Chicago: American Library Association

Badan Pusat Statistik Indonesia (2016)

Bramley, Gerry. (1991). Adult Literacy, Basic, Skills, and Libraries. London: Clive Bingley

Bungin, M. Burhan. (2007). Penelitian Kualitatif: Komunikasi, Ekonomi, Kebijakan Publik, dan Ilmu Sosial Lainnya. Jakarta: Kencana Prenada Media Group.

Clay, M. M. (2001). Change over time in children's literacy development. Porthsmouth: Heinemann dalam Direktorat Jenderal Pendidikan Dasa dan Menengah. (2016). Desain Induk Gerakan Literasi Sekolah

Kern, Richard . (2000). Literacy and Language Teaching. Oxford: Oxford University Press

Kirsch. Irwin s, dan Anna Jungeblut (2002) Literacy: Profile of America's Young Adult (TT). This report No. 16 PL-02. Can be order from the National Assessment of Education Progress at Educational Testing Service. Roscdale Road. Princeton, New Jersey 0854.

Lexy J. Moleong. (2012). Metodelogi Penelitian Kualitatif. Bandung: PT Remaja Rosdakarya

Mappiare, Andi. (1982). Psikologi Remaja. Surabaya: Usaha Nasional.

Miller, John W. dan Micahel M. McKenna. (2016). World Literacy: How Countries Rank and Why It Matters. New York: Routledge

Panduan Gerakan Literasi Nasional. (2017). Kementerian Pendidikan dan Kebudayaan Republik Indonesia

Robinson. Sharon, dan Riley. Richard.(1993). Adult Literacy in America. U.S. Department of Education. New Jersey. Avennue.

Yanto, dkk (2016). Model Aktivitas Gerakan Literasi Berbasis Komunitas di Sudut Baca Soreang. Jurnal Kajian Informasi dan Perpustakaan Vol 2/No.1 Juni 2016 Hlm 107-118. Program Studi Ilmu Perpustakaan Universitas Padjajaran.

Yulisa W, (2017). Implementasi Gerakan Literasi Sekolah (GLS) Sebagai Pembentuk Pendidikan Berkarakter. Jurnal Manajemen, Kepemimpinan, dan Supervisi Pendidikan Volume 1, No1, JuliDesember 2017 